\section{Neslihan Turguttopbas*}

\section{Perspectives on Monetary Policy and Cost of Capital: Evidence from Turkey}

\begin{abstract}
The target of monetary policy is generally set as to create an environment of manageable employment and affordable long-term interest rates. However, priorities of central banks may differ depending on economic and financial circumstances of individual countries. Modern approaches to monetary policy transmission can be grouped under two headings, Money View and Credit View. The money view concentrates on interest rates to explain the effects of monetary policy on aggregate spending by creating an interest rate channel. The credit channel transmission approach focuses on the supply of credits by banks following a monetary policy shift in interest rates. In 2010, the Central Bank of Turkey (CBT) developed an interest rate corridor shaped by one-week and overnight repo lending to the financial banks to absorb excessive volatility caused by short-term capital inflows. Under this framework, the CBT implements its monetary policy in two ways; firstly it can alter the interest rates of weekly repo as well as $\mathrm{O} / \mathrm{N}$ lending rate. Secondly, it can configure the funding structure it provides to the financial intermediaries. In such a framework, the interest rate transmission mechanism has been operated by two benchmark interest rates, one of which is the weighted average of the cost of funds provided by the CBT and the other is the interest rate in Borsa Istanbul (BIST) money market transactions at an overnight maturity. There is a strong co-movement between the interest rates and they are affected by the movements in the CBT lending rate in both directions. Interest rates applied to deposits and loans by banks are affected by the policy rate (CBT Average Funding Rate) and the market rate (BIST O/N Repo Rate).
\end{abstract}

Key Words: Monetary Policy, Transmission Channels, Money View, Credit View

Jel Codes: E52, E58
${ }^{*}$ Management Faculty, Department of Finance and Insurance, Attlim University, Kızılcaşar Mah.Incek, Ankara, Turkey

E-mail: ntopbas@atilim.edu.tr 


\section{Introduction}

The target of monetary policy is generally set as to create an environment of manageable employment and affordable long-term interest rates. However, in many countries, price stability is the main goal since with implementing effective monetary policy and maintaining stable prices central banks can motivate long-term economic growth and employment.

There are three components of monetary policy: open market operations, central bank's discount rate, and reserve requirements. Open market operations are realized by central banks by trading government securities with prices determined by the market. The discount rate is the interest rate applied by central banks to depository institutions for short-term loans. Central bank lending at the discount rate complements open market operations and serves as a backup source of liquidity for commercial banks. Lowering (rising) the discount rate is expansionary (contractionary) because the discount rate influences other interest rates. Reserve requirements affect the amount of liquidity as they determine blocked portions of deposits by the central bank. A decrease (increase) in reserve requirements is expansionary (contractionary) because it increases (decreases) funds available in the banking system to lend to consumers and businesses.

Impacts of the monetary policy to an economy have been realized through various channels and all are named as the monetary policy transmission mechanism in the literature. However, it is a fact that monetary policy changes generally have lagging effects on price movements. Figure 1 gives an illustration of the main monetary policy transmission channels.

Broad range of research have been analysed the effects of changes in the monetary policy rate on different financial institutions' financial instruments, including, but not limited to deposits with different maturities, commercial lending and mortgages. The studies have also focused on how fast a financial system reflects changes in the policy-affected market rates. It is a realized fact that the effects of monetary policy changes have been lagging partly due to the inability of financial intermediaries to adjust the interest rates. The duration of lags differs across different segments of the financial sector as financial institutions as well as financial instrument may have different adjustment rates. The standing of the current interest rates imposed by different financial institutions on different products with regard to their long-term equilibrium level also affects the speed of adjustment (Chong and friends, 2006). 
Figure 1: The Main Transmission Channels of Monetary Policy

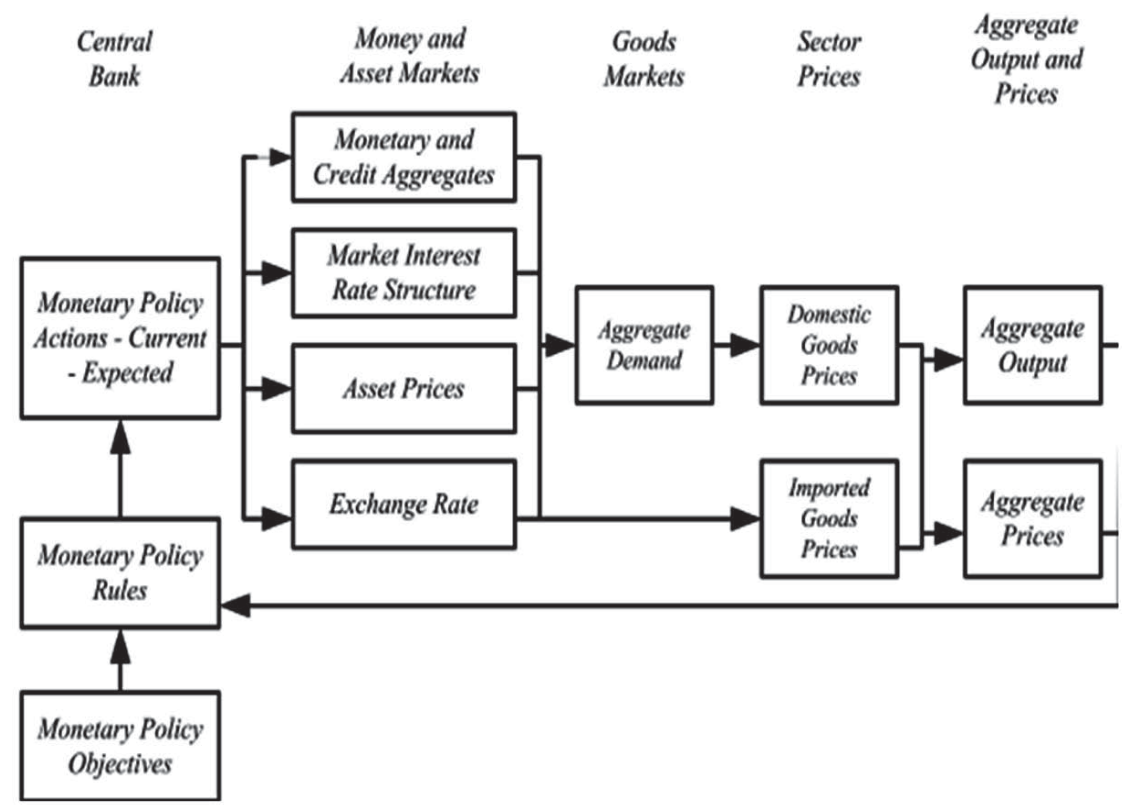

Source: Loayza \& Schmidt-Hebbel

\section{Money View on Monetary Policy Transmission}

Modern approaches to monetary policy transmission can be summarized under two main headings: Money View and Credit View which have also sub-approaches to clarify the market developments. The money view initiated by Mishkin (2010) with the main focus on the interest rate channel addressing the effects of the monetary policy on aggregate spending through changes in interest rates. The two empirically supported assumptions of the money view are; the central bank has the ability to affect the short-term nominal interest rate and there exist elasticity of investment and consumption expenditures to the real interest rate. The central bank, by determining its interest rate, can influence the term structure of the interest rates despite the lags which can be caused by many structural factors relevant to financial institutions and markets. Over time, two initiatives have also evolved under the money view, the exchange rate and asset price channels. 


\section{Interest Rate Channel}

The interest rate channel approach stipulated by Keynes focuses on the hypothesis of the term structure and proposes that an increase in the short-term monetary policy rate leads to an increase in longer-term nominal interest rates. The reasoning has been formulated as investors compare the differences in risk-adjusted expected returns on debt instruments with different maturities to utilize the arbitrage opportunities. Under this approach, the functioning of financial institutions is not figured out and the direct increase of the real costs of borrowing of the corporate sector are considered which, in turn, result in the lowering of their investment expenditures. Likewise, households also postpone their purchases of core assets homes, automobiles, and other durable goods referring to the higher real borrowing costs. The combined effect on the economy is a fall in aggregate output and employment. This interest rate channel mechanism was defined in the Keynesian textbook IS-LM model, and was originated by Hicks (1937).

\section{Exchange Rate Channel}

The research in 1960s on transmission mechanisms such as that presented by Fleming (1962), Mundell (1963), and Dornbusch (1976) mainly concentrated on the effects of changes in the short-term policy interest rates on the real economy through the exchange rate channel. Their approach relied on the uncovered interest parity and addressed that a policy-imposed increase in domestic nominal short-term interest rates as compared to foreigners' results with the expectations that domestic currency will depreciate to equate the domestic and foreign interest rates. The initial effects of longer term expectations about the domestic currency depreciation are generally in the form of an initial appreciation which makes domestic goods expensive as compared to the exported ones. The macroeconomic effects would be a decline in net exports, domestic output, and employment.

\section{Asset Price Channel}

The asset price channel approach is based on the substitution of debt instruments and issuance of shares as the source of funding for corporates in the case of policy shifts. The approach is emphasized by Tobin's (1969) q-theory of investment and the life-cycle theory of consumption postulated by Ando and Modigliani (1963). Tobin defines $q$ as the ratio of the stock market value of a corporate to the replacement cost of the physical capital owned by it. A policy-imposed increase in the short-term nominal interest rate makes debt instruments more expensive as compared to issuing shares for corporate and at the same time more attractive for investors. Tobin explains such a situation with a lower value of $\mathrm{q}$ which 
necessitates more shares to be issued in order to collect the required funds for the investment which becomes more costly. As all the real sector actors will be confronted with the same funding conditions, some of the planned investments will be postponed, if not even rejected and this will lead domestic output and employment to diminish. Ando and Modigliani's life-cycle theory of consumption explains the transmission mechanism with the fall in the wealth of households as a result of a decline in stock prices which, in turn, results in a decline in their consumption, output, and employment.

Both of the assumptions of the money view have been criticized, as relatively small shifts in monetary policy are not adequate to explain the real effects realized. The general thinking is that the monetary transmission mechanism is functioning; however, some multiplier effects are also contributing to its effects. Hubbard (1998) named the magnification of initial shocks by financial markets as "financial accelerator" which was proposed by Bernanke, Gertler, and Gilchrist (1996). Many central bankers, especially from the U.S., have contributed to the new credit view approach of policy transmission in 1990s which proposes that in addition to the traditional interest-rate channel/money view, credit market imperfections play a crucial role in explaining the effects of monetary policies on economy (See Gertler and Gilchrist (1993), Bernanke (1993), Bernanke and Gertler (1995), Cecchetti (1995), Hubbard (1994), Oliner and Rudebusch (1996)). There exists an agreement that money view and credit view share a common starting point and are complementary, which implies the simultaneous coexistence of the two transmission channels.

\section{Credit View on Monetary Policy Transmission}

The credit channel transmission approach focuses on the supply of credits by banks following a monetary policy shift in interest rates. It proposes that in the case of an increase in the key rates imposed by the central bank, the refinancing requirements of banks and households deteriorate. The immediate effect of such worsening of refinancing ability will be realized in the form of tight lending capability of banks which, in turn, will negatively affect the economic growth. On the other side, the refinancing problems confronted by the real sector may further deteriorate a bank's positioning by increasing the non-performing loans.

In many economies, banks, by providing funds for investment, play a vital role for the real economy as the bank lending the major funding source for companies. Therefore, economic output level through new investments appears to be sensitive to fluctuations in bank lending behaviour. Any tightening of monetary 
policy is expected to cause asset reallocation in the bank balance sheets which leads to tighter lending capacity to companies. Such tightening generally creates both a supply effect by reducing the available loan-able funds of banks through credit channel and a demand effect by higher borrowing rates for companies through the interest rate channel.

In order to determine the significance of credit view on the reaction of economic activity to monetary policy changes, limitations in the banking system should be elaborated. One of these market imperfections is informational asymmetry between a lender and a borrower which makes the costs of internal and external funds to differentiate. This is named "external finance premium" by Bernanke and Gertler (1995) and it reflects the cost of evaluating, monitoring and administering the borrower, cost arising from informational asymmetry between the lender and the borrower about the financial position of the borrower and the expected costs associated with moral hazard of the borrower. Credit view includes two different views: the balance sheet channel and the bank lending channel (Bernanke and Gertler (1995), Lensink and Sterken (2002)).

\section{Balance Sheet Channel}

The balance sheet channel focuses on the effect of monetary policy on the financial position of borrowers. The leverage level of a corporate as well as the terms of lending imposed by the market affects investment and spending decisions of the corporate. The proposed process relies on two common implications. First, borrowing is generally more expensive than internal financing, but external financing is inevitable in order to realize new investments. Second, the borrower's net worth level consisting of internal funds and assets as compared to the amount of funds required has a negative relation with the cost of external funding. The borrowers' financial position may be affected by an adverse shock due to an increase in interest expenses, a decline in the value of collateral as a result of declining asset prices, or a decrease in the demand for its products.

This channel clearly defines the case of economic slow-down when firms' net worth will probably decline and cost of borrowing increases further, causing the initial negative shock to the economy to be amplified. It is also empirically supported that a firm size makes a difference in terms of vulnerability of the corporate to monetary policy tightening. As small firms have disadvantage in terms of agency costs and dependency on bank financing, they are more likely to be affected by a tightening in the monetary policy (Gertler and Gilchrist (1994) and Lamont and Rossen (2007) for the United States, Rondi, Sack, Schiantarelli, and Sembenelli (1998) for Italy, Mojon et al. (2002) for EU countries: Germany, 
France, Italy, and Spain). The balance sheet channel predicts "flight to quality," meaning that when monetary policy is tight, banks prefer large firms rather than smaller ones.

\section{Bank Lending Channel}

The bank lending channel focuses on changes in the composition of bank balance sheets in response to monetary policy changes. For the bank lending channel to work, three main conditions should exist, as specified by Kashyap and Stein, 1995a); first, price-stickiness must exist. Second, some companies relying solely on bank lending must exist as they have no access to the capital markets. Third, the central bank must have control over the loan supply schedules of banks.

A tight monetary policy by restricting the supply of free funds of the banking system causes the external finance premium of the bank-dependent borrower firms to increase. However, the effects of the policy shifts on the bank lending activates also depend on the structures of the balance sheets as has been analysed by many researchers. The early researchers focused on banks size; Kashyap and Stein (1995b) using U.S. data was amongst the first that found evidence that size makes difference in relation to vulnerability of banks to changes in monetary policy. Small banks with less free funds are more affected by tight monetary policies than large banks. The size affect is sourced by problems of asymmetric information as small banks have more difficulties substituting non-deposit sources of external finance. Altunbas et al. (2002) and Kakes and Sturm (2002) analysed the bank lending in Europe and revealed that smaller banks have more difficulties in neutralizing monetary shocks than large banks. Capital strength was another attribute analysed, less capitalized banks have to restrain lending as a response to tight monetary policy more quickly to keep financial soundness (Altunbas et al. (2002), Kishyan and Opiela (2000), Gambacorta and Mistrulli, 2004; Altunbas, Gambacorta and Marqués, 2009a). Even well capitalized banks may be urged to reallocate their loan portfolios with a cautious approach for future regulatory capital requirements (Van den Heuvel, 2002). Liquidity was another factor directly affecting the bank lending channel as banks with higher liquidity have the ability to refund their loan portfolios and have less motivation to lower their lending in times of monetary tightening (Kashyap and Stein (2000), Ashcraft (2001).

\section{Monetary Policy of Central Bank of Turkey}

The monetary policy of the Central Bank of Turkey (CBT) was shaped in the aftermath of the November 2000 and February 2001 crises. Originally, monetary 
targeting and inflation targeting were set as two nominal anchors and the CBT began to follow both monetary targeting and future inflation-targeted monetary policy. Such an implementation was represented as an "implicit inflation targeting", however, the intention was to move to official inflation targeting when market conditions permit. Until the commencement of inflation targeting, the CBT expressed its intention to use short-term interest rates against inflation and the monetary policy focused entirely on inflation expectations. It was acknowledged that the financial environment represented by relatively less volatility in shortterm interest rates was a precondition for the success in disinflation. The "late liquidity window" in the interbank money market facility was provided by the CBT to provide funding to the banks against collateral.

After the realization of gradual decrease in volatility, the floating exchange rate regime was introduced in February 2001. The stabilization of the financial markets increased the daily volume of transactions in the interbank money market where "Turkish Lira reference interest rate" was stipulated. The reference interest rate is considered to be the benchmark in the pricing of financial instruments and forward foreign exchange. However, the intention of the CBT was a gradual phasing out of its intermediary role in order not to create distorted pricing mechanisms.

During the period between 2001 and 2005, in order to create a suitable framework for the inflation-targeting regime, the institutional infrastructure of monetary policy gradually improved. The CBT began to implement inflation targeting as the main tool of monetary policy in 2006 in order to transform the process from price stability to disinflation. Within the context of inflation-targeting regime, the Monetary Policy Committee was activated as a decision maker and began to meet once a month.

Liquidity management strategy of the CBT, formulize main policy interest rates on the basis of following settlements:

- Overnight borrowing and lending interest rates in the interbank money market is announced by the CBT. The banks can fulfil unexpected liquid needs by borrowing at the Central Bank's lending interest rate within their limits. Whenever liquidity increases, the CBT absorbs it by borrowing from banks at the borrowing interest rate.

- Late Liquidity Window facility is created to enable the banks to borrow from the Central Bank against collateral and also lend in between a.m. 16.00-16.30 to Central Bank. 
- At the beginning of 2006, then CBT began applying the strategy of interest rate corridor in which the lending interest rate is determined as 3\% higher and the borrowing interest rate as $4 \%$ lower than the daily borrowing interest rate.

- In times of policy rate determination, the CBT absorbs excess liquidity by one-week maturity borrowing interest rate. In order to avoid temporary fluctuations in overnight interest rates, the CBT will not operate at the interbank money market for one-week maturity borrowing interest rate and at the Istanbul Stock Exchange reverse repo market.

- In case of liquidity shortage, the CBT manages liquidity through one-week maturity repo auctions referring to its commitment about maintaining the average of auction interest rate at approximately $1 \%$ over the daily CBT borrowing interest rate in the interbank money market.

- Whenever temporary excessive liquidity shortage occurs that would excessively push the interest rates in the money market during the day, "Intraday Repo Auctions" are to be held by the CBT as an easing tool.

- Whenever permanent liquidity shortage occurs, the repo auction interest rate is considered to be the benchmark short-term interest rate in the place of the CBT daily borrowing interest rate.

\section{Literature on Monetary Policy of the Central Bank of Turkey}

Cavusoglu (2002) analysed the monetary policy in Turkey before the 2002 era and indicated that there was no bank lending channel during the 1988-1999 period. The 1997-1999 period was also analysed by Sengonul and Thorbecke (2005) and they reported that liquidity had an effect on bank supply. Brooks (2007) was not able to empirically prove that the bank lending channel operates in Turkey despite the fact that banks do have an important role in the economy and she addressed the liquidity position of the Turkish banking sector.

The sensitivity and speed of adjustment of the interest rate applied to the corporate, housing, cash, and automobile loans was analyzed by Aydin (2006). It is stated that the long-term pass-through to cash and automobile loans is one-toone and that it is also greater than unity for housing loan rates. Surprisingly, the corporate loans are not that sensitive to monetary policy rate changes.

Özşuca et al. (2012) investigated the impact of monetary policy changes on the lending behaviour of banks in the period of 1988-2009 and they empirically determined that there were cross sectional heterogeneity in banks' response to monetary policy. The analysis is further conducted for the two sub-periods: 1988- 
2001 and 2002-2009 in order to address the structural changes after the 2001 crisis, it is determined that bank lending channel existed in the 1988-2001 period. Aydin and Igan (2010) questioned the strength of the bank lending channel in Turkey and suggested that it is not that strong as the government finances have a limited direct impact on credit. Turkish banks have permanent liquidity needs and consequently the lending activity diminishes sharply during contractionary monetary policies and it has limited effects on the banks with a retail banking focus.

Çatık and M. Karaçuka (2012) analysed the 1986-2009 period and reported that the interest rate channel is only applicable for the post inflation targeting period. They also expressed that the effect of monetary policy changes on credit volume is very limited especially in the low inflation period. Butkiewicz and Ozdogan (2013) focused on the importance of central bank independence and a credible monetary policy and reported that in the post-2001 crisis period, the ability of the central bank to stabilize output was increased and monetary policy of the CBT had strong and persistent effects on real output. Avc1 and Yucel (2016) analysed the effectiveness of monetary policy in Turkey by focusing on the interest rate pass-through behaviour and determined that policy rate innovations transmit fully in less than eight months.

Recent studies about the Turkish monetary policy and transmission mechanisms have been taken by the central bank experts. Başçı and friends (2007) emphasized the role of the CBT short term interest rates as the primary tool for shaping expectations. They analysed the May-June 2006 turbulence and the stance of the CBT against it through the monetary policy and pointed out that tight monetary policy was successful to create the desired effects and the role of monetary policy in determining key macroeconomic variables has strengthened. Binici et al. (2013) focused on the asymmetric interest rate as applied by the CBT and stated that it can also be used as a tool to smooth the business cycle fluctuations to mitigate the excessive volatility.

They analysed the interaction between the interest rate corridor and the creditdeposit spread which is considered to be the measure of risk appetite for lending by banks. They indicated that through the use of the asymmetric corridor policy and liquidity management strategy together, monetary policy is able to affect credit and deposit rates. Küçük et al. (2014) concentrated on the wide interest rate corridor policy tool developed by the CBT in the second half of 2010 when there was excessive volatility resulting from short-term capital inflows. 


\section{The CBT Interest Rate Corridor}

Referring to the announcement of Monetary and Exchange Rate Policy for 2016 ${ }^{1}$, the CBT maintains the price stability-oriented monetary policy framework. It continues to operate under the dual targets of realizing inflation close to the target and supporting financial stability. On 18 August 2015, the CBT indicated the policy of a more narrow and symmetric interest rate corridor.

Since the last quarter of 2015, the CBT has implemented a tight monetary policy against inflationary expectations and it has also been active in stabilizing foreign exchange liquidity in order to secure financial stability. The tight monetary policy has succeeded in keeping annual loan growth at reasonable levels and rebalancing the economy as commercial loans have continued to grow at a faster rate compared to consumer loans. The main instrument of the monetary policy has been short term interest rate structure in countries where inflation targeting policy has been followed together with floating exchange rate regime. In such a framework, the CBT used one-week and overnight repo operations to set the short term interest rates under the condition that there exists adequate liquidity in the market.

Figure 2: The CBRT Interest Rate Corridor, Weighted Average Funding Cost

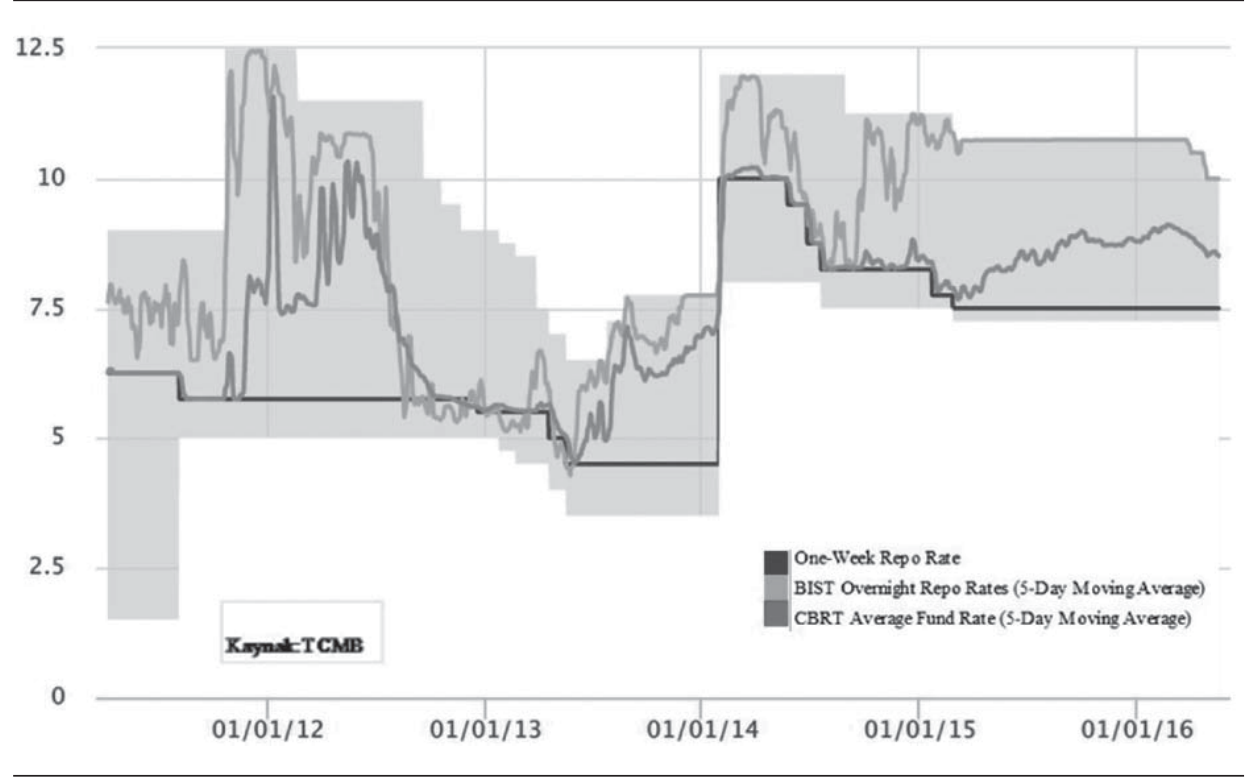

1 http://www.tcmb.gov.tr/wps/wcm/connect/0bb6b09b-df1e-4346-8194-fbae0239cad9/2016. pdf?MOD=AJPERES 
Figure 2 shows the CBT Interest Rate Corridor which was narrowed and designed to be more symmetric around the one-week repo rate in mid-2015. Typically, the conventional interest rate corridor has been characterized with the co-movement of all short term interest rates with similar or same magnitude size. The interest rate corridor policy of the CBT differs from the traditional ones as the extent of movements and directions of various rates may occasionally depart from each other and implications of these movements for the monetary policy stance is less clear.

Figure 3: Determination of Interest Rates by the CBT

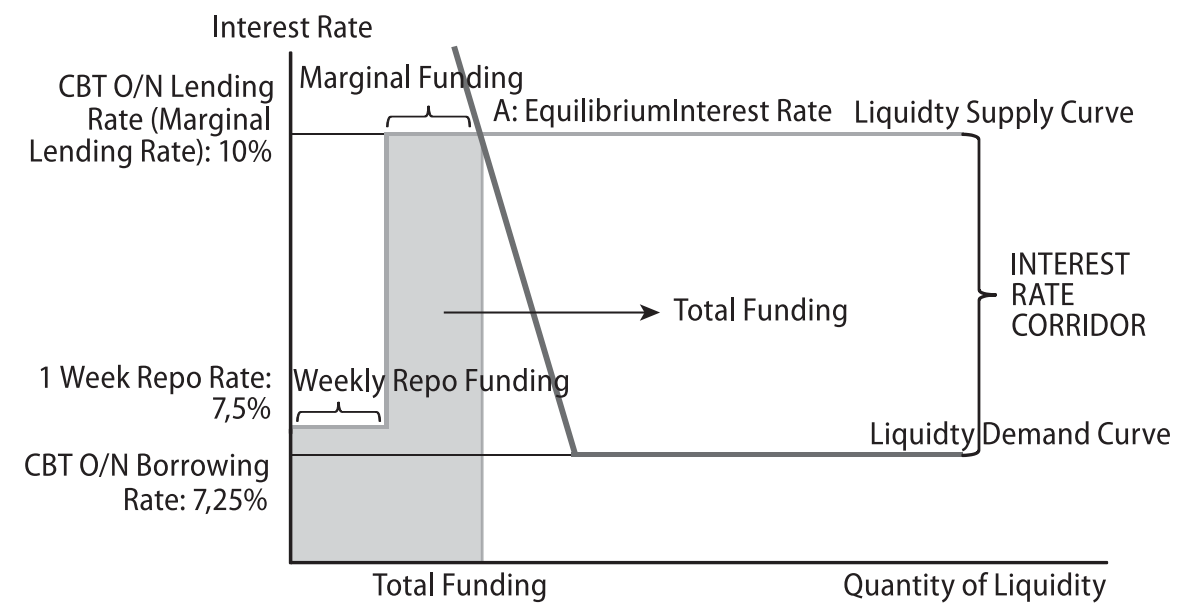

Figure 3 shows how the CBT determines the short term interest rates by supplying liquidity under $\mathrm{O} / \mathrm{N}$ lending in interbank market and weekly repo lending through auctions via the quantity auction method. The rates specified in Figure 3 are all real-time rates as of May 2016. Two main sources of liquidity have been provided with different interest rates and the supply of the one-week repo facility has been directly determined by the CBT, the supply curve has stepwise form. Utilizing the one-week repo facility under the terms set by the CBT, the banks use overnight borrowing when they need additional liquidity. At the point of the CBT borrowing rate, the theoretically downward sloping demand curve becomes flat as the market interest rates never falls below it. The equilibrium interest rate is the rate at the intersection of the supply and demand curves (point A) and at this point some of the liquidity is provided through one-week repo and the rest through the more expensive marginal funding facility. 


\section{Monetary Policy and Cost of Capital}

The CBT implements its monetary policy in two ways; firstly, it can alter the interest rates of weekly repo as well as $\mathrm{O} / \mathrm{N}$ lending rate and announce this to the public during the monthly Monetary Policy Committee meetings. Secondly, the CBT can change the funding composition (the share of one-week repo in total funding) to be provided to financial intermediaries. While changes in the interest rates directly affect the funding costs of the banks, changes in the composition indirectly alter the equilibrium interest rate in a range from one-week repo rate to the marginal funding rate. A tightened policy forces banks to borrow from the CBT more at the weekly repo rate causing an upward shift in the funding costs, without changing the officially announced short-term interest rates.

In such a framework, the interest rate transmission mechanism has been operated by two benchmark interest rates, one of which is the weighted average of the cost of funds provided by the CBT through several channels. This rate has deterministic power on all short term interest rates as funding provided by the CBT constitutes a sizeable portion of the banks' short-term Turkish lira funding at any time, referring to Figure 4. Figure 4 also displays a stable share of one-week repo funding in total CBT funding and a gradual increase in the marginal funding beginning from March 2015.

Figure 4: Short-Term Funding Provided by the CBT

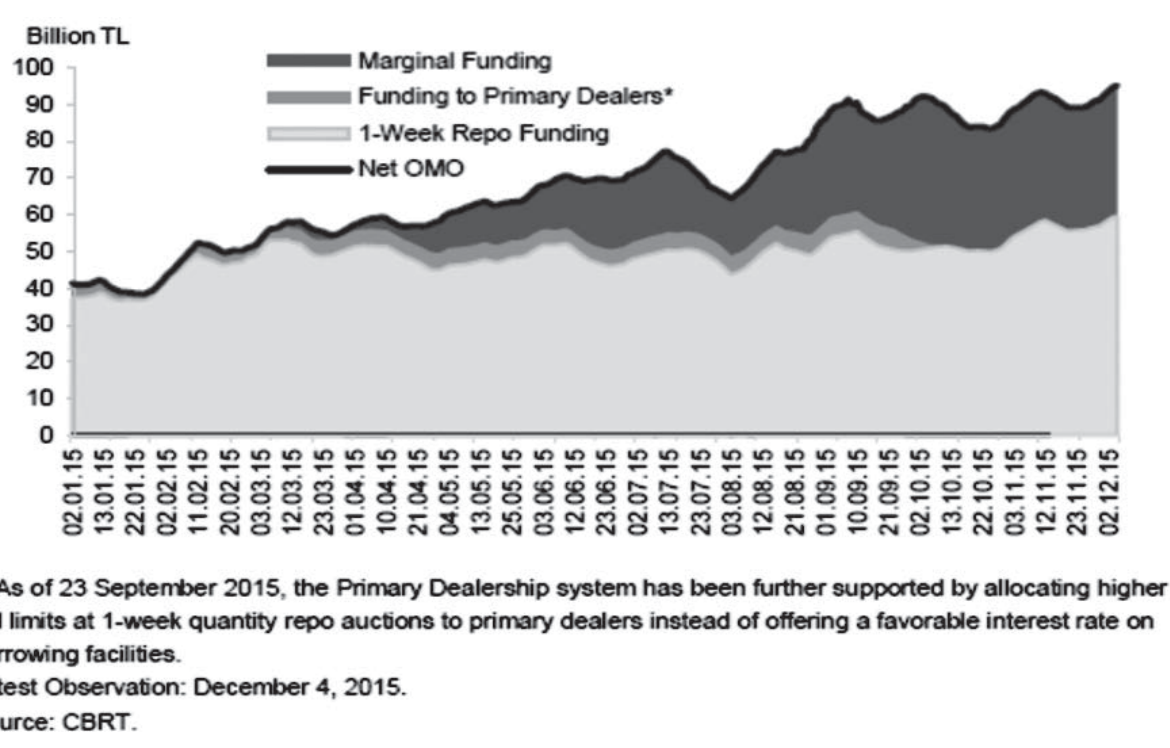


The other benchmark interest rate is relevant with Borsa Istanbul (BIST) money market transactions at an overnight maturity. Referring to Figure 4 above, the Borsa Istanbul overnight repo interest rate fluctuates more inside the corridor and it can even move far away from the average funding rate. The spread between the overnight market rate and the CBRT average funding rate which is named as overnight spread has become wider and more volatile in the period following the adoption of the new framework.

Figure 5: Overnight Spread Fluctuations

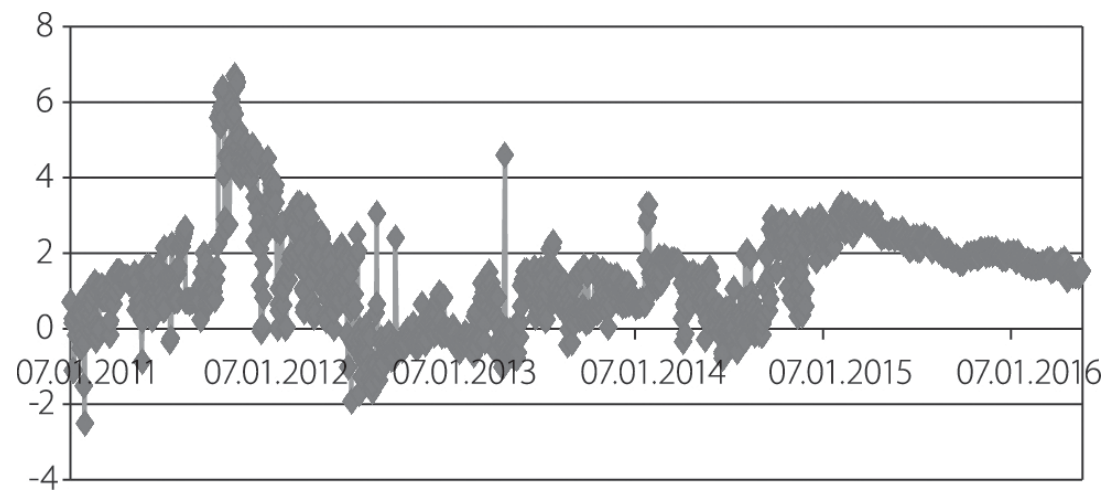

The CBT influences the interest rates in the interbank market through the parameters of the interest rate corridor under the liquidity policy. It is a fact that the interbank $\mathrm{O} / \mathrm{N}$ rate has deterministic power on the short term funding costs of the banks as it also affects other money market sources such as cross-currency swaps. In this regard, the interbank $\mathrm{O} / \mathrm{N}$ rate has a vital role for an operating monetary transmission mechanism (Kara, 2015) and it also has influential power in the pricing of deposits, loans and other financial instruments. 
Figure 6: Interest Rate Corridor of CBT and Bank Lending Rates

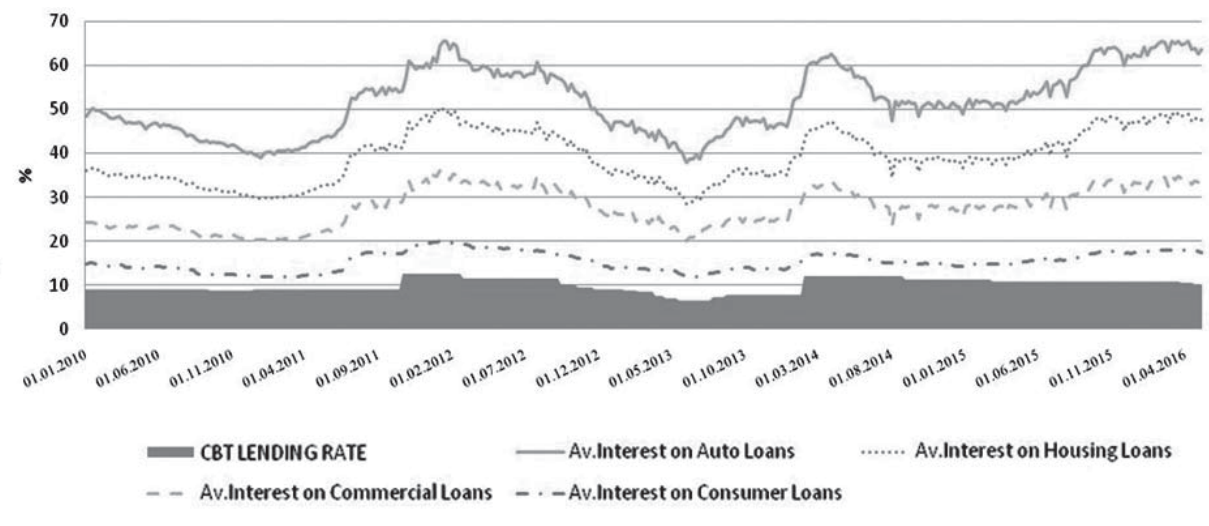

Figure 6 displays the interest rate corridor of the CBT and the average interest rates applied to various loan types in TL by Turkish banks since 2010. There is a strong co-movement between the interest rates and they are affected by movements in the CBT lending rate in both directions. Although interest rates applied to loans have been affected by various factors, including, but not limited to banks' liquidity, business cycle-related factors affecting loan demand, the movements in the CBT lending rate have reflected on loan interest rates. The effects are sharper for the loans to households (auto and housing) than for commercial and consumer loans.

Figure 7: Cost of Capital of Turkish Banks

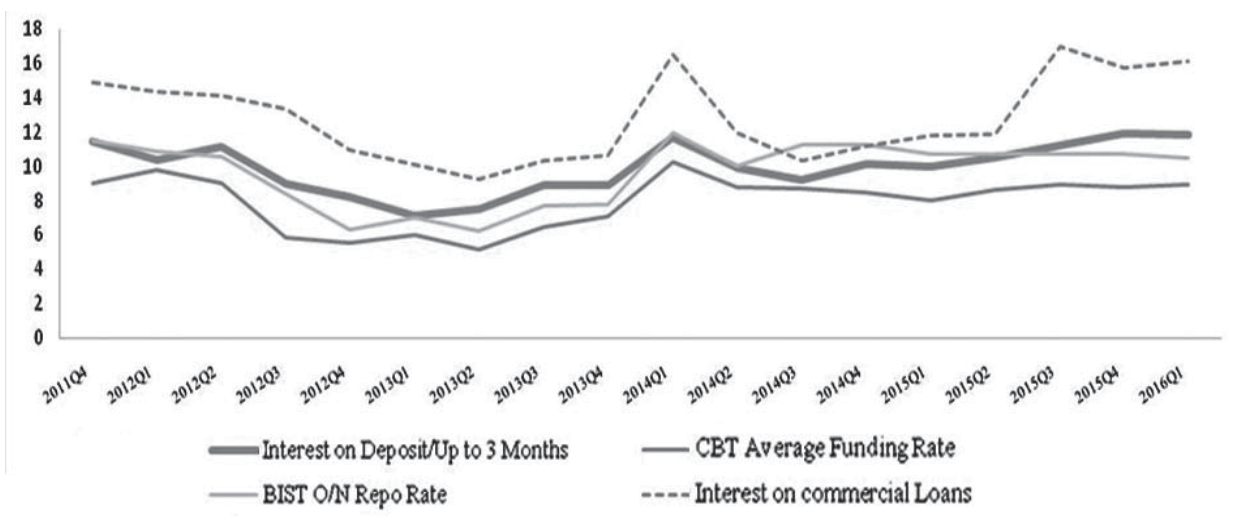


Apart from the paid-in capital, the main source of TL funding of Turkish banks is deposits as $73 \%$ of loans denominated in TL has been financed by deposits as of May 2016. Although there is no standard definition in academic literature or global practices, the core liabilities ratio, as expressed by the CBT and calculated as the ratio of the total of deposits and equity to loans, diminished gradually from the level of $114 \%$ in 2012 to $98 \%$ in March 2015. The average maturity of TL deposits has been less than 2 months as nearly $60 \%$ of TL deposits are composed of deposits with maturities between 1 and 3 months ${ }^{2}$. In these circumstances, Figure 7 shows the co-movement of the interest rates applied to TL deposits by banks with the policy rate (CBT Average Funding Rate) and the market rate (BIST O/N Repo Rate), as well as the interest rate imposed to commercial loans by banks.

\section{Conclusion}

The goals of monetary policy are generally set as to promote stable prices, maximum employment, and moderate long-term interest rates. However, priorities of central banks may differ depending on economic and financial circumstances of individual countries. The modern approach to monetary policy transmission can be summarized under two headings: Money View and Credit View. The money view focuses on the traditional interest-rate channel, which explains the effect of monetary policy on aggregate spending through changes in interest rates. The credit channel transmission approach focuses on the supply of credits by banks following a monetary policy shift in interest rates. Monetary policy of the Central Bank of Turkey (CBT) was shaped in the aftermath of the November 2000 and February 2001 crises. Originally, monetary targeting and inflation targeting were set as two nominal anchors and the CBT began to follow monetary targeting and at the same time implement monetary policy focused on future inflation. In 2010, the CBT developed an interest rate corridor shaped by one-week and overnight repo lending to financial institutions to smooth excessive volatility in short-term capital inflows. Under this framework, the CBT implements its monetary policy in two ways: firstly, it can alter the interest rates of weekly repo as well as $\mathrm{O} / \mathrm{N}$ lending rate and announce that to the public during monthly Monetary Policy Committee meetings. Secondly, the CBT can change the funding composition (the share of one-week repo in total funding) to be provided to financial intermediaries. In such a framework, the interest rate transmission mechanism has been operated by two benchmark interest rates, one of which is the weighted average

\footnotetext{
2 http://www.tcmb.gov.tr/wps/wcm/connect/7450aef8-0046-4b2c-9388-1b44e51835de/ sectionIII-20.pdf?MOD=AJPERES\&CACHEID=ROOTWORKSPACE7450aef8-0046-4b2c9388-1b44e51835de
} 
of the cost of funds provided by the CBT and the other is the interest rate relevant with Borsa Istanbul (BIST) money market transactions at an overnight maturity. However, it is a fact that there is a strong co-movement between the interest rates and that they are affected by the movements in the CBT lending rate in both directions. There is also co-movement of the interest rates applied to TL deposits by banks with the policy rate (CBT Average Funding Rate) and the market rate (BIST O/N Repo Rate), as well as the interest rate imposed to commercial loans by banks. 


\section{References}

1. Ahn, J.J., Oh,K.J., Kim,T.Y.,\& Kim, D.H. (2011). Usefulness of suppot vector machine to develop an early warning system for financial crisis. Expert System with Applications, 38(4),2966-2973

2. Altunbas, Y., Fazylov, O.\& Molyneux, P. (2002). Evidence on the bank lending channel in Europe. Journal of Banking and Finance, 26, 2093-2110

3. Altunbas, Y., Gambacorta L.\& Marques-Ibanez, D. (2009). Securitisation and the bank lending channel. European Economic Review, 53(8), 996-1009.

4. Ashcraft, A.(2006). New Evidence on the Lending Channel. Journal of Money, Credit and Banking, 38, 751-76.

5. Aydin, H. I. (2007). Interest rate pass-through in Turkey. Research and Monetary Policy Department Working Paper, CBT No: 07/05.

6. Aydin, B., Igan, D. (2010). Bank Lending in Turkey: Effects of Monetary and Fiscal Policies. Working Paper, IMF WP/10/233.

7. Başç, E., Özel, Ö., Sarıkaya, Ç. (2007) The monetary transmission mechanism in Turkey: new developments. BIS Papers No 35.

8. Bernanke, B. (1993). Credit and the Macroeconomy. Federal Reserve Bank of New York Quarterly Review, XVIII (1993), 50-70.

9. Bernanke, B.S., \& . Gertler, M. (1995). Inside the Black Box: The Credit Channel of Monetary Policy Transmission. Journal of Economic Perspectives, 9, 27-48.

10. Bernanke, B., Gertler, M., \& Gilchrist, S.(1996). The Financial Accelerator and the Flight to Quality. The Review of Economics and Statistics, 78(1), 1-15.

11. Binici, M., Erol, H., Kara, H., Özlü, P. \& Ünalmış, D. (2013) Interest Rate Corridor: A New Macroprudential Tool? CBT Research Notes In Economics, No: 2013-20.

12. Butkiewicz, J.L., Ozdogan, Z. (2013). Financial crisis, monetary policy reform and the monetary transmission mechanism in Turkey. Research and Monetary Policy Department Working Paper, No:07/04

13. Cavusoglu, T. (2002). Credit Transmission Mechanism in Turkey: An Empirical Investigation. ERC Working Papers in Economic, Ankara: Middle East Technical University.

14. Cecchetti, S.G.(1995). Distinguishing theories of the monetary transmission mechanism. Proceedings, Federal Reserve Bank of St. Louis, 83-97.

15. Chong, B.S., Liu, M., \& SHRESTHA, K. (2006). Monetary transmission via the administered interest rates channel. Journal of Banking and Finance, 30(5), 1467-1484.

16. Çatık, N., Karaçuka, M. (2012). The Bank Lending Channel in Turkey: Has it changed after the Low inflation Regime? Applied Economics Letters, 19(13), 1237-1242. 
17. Dornbusch, R. (1976). Expectations and Exchange Rate Dynamics. Journal of Political Economy, 84, 1161-1176.

18. Fleming, J.M. (1962). Domestic Financial Polices Under Fixed and Under Floating Exchange Rates. International Monetary Fund Staff Papers, 9, 369-379.

19. Gambacorta, L., Mistrulli, P.E. (2004). Does bank capital affect lending behavior? Journal of Financial Intermediation, 13(4), 436-57.

20. Gertler, M., Gilchrist, S. (1993). The Role of Credit Market Imperfections in the Monetary Transmission Mechanism: Arguments and Evidence. Scandanavian Journal of Economics, LXCV, 43-64.

21. Hicks, J.R. (1937). Mr. Keynes and the "Classics". A Suggested Interpretation. Econometrica, 5, 147-159.

22. Hubbard, R. G.(1994). Is There a 'Credit Channel' for Monetary Policy? NBER Working Papers , 4977.

23. Hubbard, G.R.(1998). Capital market imperfections and investment. Journal of Economic Literature, 36, 193-225.

24. Kakes, J., Sturm, J.E. (2002). Monetary policy and bank lending: Evidence from German banking groups. Journal of Banking and Finance, 26, 20072092.

25. Kara, H. (2015) Interest Rate Corridor and the Monetary Policy Stance, TCMB Research Notes In Economics, No: 2015-13.

26. Kashyap, A.K., Stein, J.C. (1995a). Monetary policy and bank lending. In: Mankiw, N.G. (Ed.), Monetary Policy. Chicago University Press, Chicago, IL, 221-256.

27. Kashyap, A.K., Stein, J.C. (1995b). The impact of monetary policy on bank balance sheets. Carnegie- Rochester Series on Public Policy 42, 142-196.

28. Kashyap, A., Stein, J.(2000). What Do One Million Observations on Banks Have to Say About the Transmission of Monetary Policy. American Economic Review, 80, 1183-200.

29. Kishyan, R.P., Opiela, T.P.(2000). Banks size, bank capital, and the bank lending channel. Journal of Money, Credit, and Banking, 32 (1), 121-141.

30. Küçük, H. ,Özlü, P., Talaslı, A., Ünalmış, D. \& Yüksel, C. (2014). Interest Rate Corridor, Liquidity Management and the Overnight Spread. CBT WorkIng Paper No: 14/02

31. Lamont K. B., Rosen, R.J.(2007). How the credit channel works: differentiating the bank lending channel and the balance sheet channel. Working Paper Series, WP-07-13, Federal Reserve Bank of Chicago.

32. Mishkin, F., S.(2010) The Economics of Money, Banking, and Financial Markets. Prenitce Hall.

33. Mojon, B., Smets, F., Vermeulen, P., 2002. Investment and monetary policy in the euro area. Journal of Banking and Finance , 26(11), 2111-2129 
34. Mundell, R.A.(1963). Capital Mobility and Stabilization Policy under Fixed and Flexible Exchange Rates. Canadian. Journal of Economics and Political Science, 29, 475-485.

35. Özsuca, E. A., Akbostanc1, E. (2012). An Empirical Analysis of the Risk Taking Channel of Monetary Policy in Turkey. ERC Working Papers No. $12 / 08$.

36. Sengonul, A., Thorbecke, W.(2005). The Effect of Monetary Policy on Bank Lending in Turkey. Applied Financial Economics, 15, 931-34.

37. Van den Heuvel, S.(2002). Does Bank Capital Matter for Monetary Transmission?. Economic Policy Review, 8, 161-72.

38. Vapnik, V.(1995). The Nature Of Statistical Learning Theory. Newyork: Springer 